\title{
Reimagining Madiba's Merc and a 'Thank You' Postcard as Objects of Social Cohesion in a South African Higher Education Institution
}

Gladys M. Ashu

ORCID iD: https://orcid.org/0000-0002-0083-2320

Mandisa Nonceba Dhlula-Moruri

ORCID iD: https://orcid.org/0000-0002-0622-1870

Mukund Bahadur Khatry-Chhetry

ORCID iD: https://orcid.org/0000-0001-9322-5572

Elizabeth Pamela Mavume

ORCID iD: https://orcid.org/0000-0002-6388-3168

Lazarus Mulenga

ORCID iD: $\underline{\text { https://orcid.org/0000-0001-6523-4658 }}$

Kholekile Hazel Ngqila

ORCID iD: https://orcid.org/0000-0002-7135-0513

Tholani Tshuma

ORCID ID: https://orcid.org/0000-0002-0564-6738

\section{Abstract}

This paper examines the late Nelson Mandela's Mercedes (Merc) Benz SClass car and a 'Thank You' postcard from the Sisters of Santa Chiara as not just objects but emblems of selflessness, togetherness, and sacrifice. The car 
and the card images serve as a foundation for inquiry, representation, and transformation for higher education. As a team of self-reflexive practitioners from various disciplines at one university in South Africa, we seek to add an alternative dimension to the current debates on social cohesion by using image-based research to generate verbal discussion and provide a critical platform from which to examine transformation. The study seeks to answer the question, What can we learn about social cohesion in higher education through object inquiry? Methods used include visual methodologies and collaborative object inquiry through reflexive Ubuntu. The visual methods unveiled different strata of meanings, evoking deep emotions, memories and ideas. Thus, having these polysemic voices helped us to have a broader understanding of fostering social cohesion in both our professional practices and everyday living. The Ubuntuism demonstrated by the owners and workers from the Mercedes Benz plant and the Sisters of Santa Chiara has a lot to teach us on social cohesion and transformation. The lessons we learnt relate to collaboration, self-sacrifice and selflessness, cultural change, and diversity and leadership.

Keywords: transformation, social cohesion, self-reflexive, image-based, meanings, Ubuntu

\section{Introduction}

Academic institutions are faced with the reality of transforming their practices and their ways of knowing to achieve social change and social cohesion within and across institutions of higher learning in South Africa. Social cohesion is meant to bring communities together and help build solidarity, trust, and inclusion (Sayed \& Badroodien 2016:3). Hence, people/institutions are encouraged to work together in the process of selfexamination and collaborative inquiry. Only when academics meaningfully change their personal capacities and thinking can they contribute to institutional transformation and social cohesion initiatives (Sayed et al. 2016:8). Additionally, Scott (2014) highlights the importance of critical reflexivity to demonstrate how academics need to negotiate both collectively and as individuals their journeys to achieve transformation for social cohesion. However, a transformative social cohesion agenda at universities 
is unlikely in policy environments that deal with diversity and difference in fragmented and individualistic ways. Badat (2010) further states that the transformation agenda in higher education is inconsistent in that institutions seek to concurrently pursue many values and goals that are in tension with one another.

The foregoing happens, in part, because higher education in South Africa exhibits legacies of the colonial past, as demonstrated by the continued presence of previously disadvantaged and previously advantaged institutions. These often still appear to be working in isolation as designed by the apartheid system. Chisanga and Meyiwa (2019:13-14) make this point when they observe, 'our university determines boundaries for its researchers, including the way in which they are expected to conduct and produce knowledge'. The authors' statement can be interpreted to mean that for an extended period after apartheid ended, previously disadvantaged and previously advantaged higher education institutions were finding it difficult to work together, even though they need one another. Nevertheless, as a Development Bank of South Africa Report proposed (Badat 2010: 33), change should be characterised by 'ruptures and discontinuities with the past resulting in a recasting of higher education values, goals and policies' and the emergence of new institutional behaviour. This suggestion is currently being implemented; some previously advantaged institutions are beginning to collaborate with previously disadvantaged institutions to nurture their growth in research (Harrison et al. 2012).

Such a transformative agenda should begin with institutional programmes that engage with diverse understandings of social cohesion by students and academics (Sayed et al. 2016). Therefore, incorporating African indigenous ideas that encourage restoration of communal harmony, such as Ubuntu (Ngcoya 2009), in the curricular and general practice could contribute towards the processes of transformation within and across institutions of higher learning. As Ngcoya (2009:1) points out, 'Ubuntu stresses the importance of community, solidarity, caring, and sharing. This worldview [Ubuntu] advocates a profound sense of interdependence and emphasizes that our true human potential can only be realized in partnership with others'.

This paper begins by considering what social cohesion is. We then introduce ourselves as the authors and provide a brief background of our activities leading to this study. Next, we present the theoretical framework 
and methodologies guiding the study. The selected objects of inquiry are then offered, together with their denotative meanings. Furthermore, our connotative perspectives on the objects and our reflections are presented. The study moves to discuss the themes that emerged from it, and conclusions are drawn concerning the broader significance and implications.

\subsection{Defining Social Cohesion}

The sociologist Émile Durkheim first devised the concept of social cohesion in 1897, defining it as 'a characteristic of a society that shows the interdependence between individuals' (Fonseca, Lukosch \& Brazier 2019:234). These characteristics included shared loyalties, mutual moral support, social capital, lack of social conflict, strong social bonds, and trust. In postapartheid South Africa, social cohesion has become a sought-after model of social change. It has been presented as a 'solution, or the antithesis of, social alienation; social problems caused by industrialisation, capitalism, and urbanisation; social polarisation along racial, ethnic or nationalist lines; inequality; deprivation resulting from the decline of the welfare state; and the exclusion of the immigrant' (Mkhize 2019:28). Social cohesion has also been approached from different angles and investigated in varied disciplines such as education, public health, and social sciences. Hence, the various definitions of the concept.

Moiseyenko (2005) defines social cohesion as the social networks and the norms of reciprocity and trustworthiness that arise from connections among individuals. The World Bank moves beyond this individualistic view to see it as a 'societal, not an individual, phenomenon that includes the level of trust and understanding of shared principles among groups in a society' (Nesterova, Dielini \& Zamozhskyi 2019:20). The World Bank definition is similar to that provided by the South African Department of Arts and Culture (DAC):

... a community or society is cohesive to the extent that the inequalities, exclusions, and disparities based on ethnicity, gender, class, nationality, age, disability or any other distinctions which engender divisions, distrust and conflict are reduced and/or eliminated in a planned and sustainable manner. This, with community members and citizens as active participants, working together for the attainment 
of shared goals, designed and agreed upon to improve the living conditions for all (Mkhize 2019:35).

The above definitions show many angles of social cohesion, the individual, society, as well as the individual and society combined. These varied angles of studying social cohesion have been affirmed by Kantzara (2016), who states that research shows three analytical levels of social cohesion: individual, group, and macro or structural. The individual level focuses on the characteristics of people that facilitate their societal participation, for example, being a member of an association, labour related, and/or doing voluntary work. At this level of analysis, cohesive factors identified include the degree of tolerance, acceptance of others in society, and the degree of trust in the functioning of public institutions or other people. The group level focuses on ties holding members together even when some of the members leave it. Meanwhile, at the macrolevel, issues of democracy, equity, tolerance, trust and social justice are regarded as the most essential factors to societal cohesion, as well as institutions that promote and practise these principles.

Notwithstanding the different definitions and levels of analysis of social cohesion, common among them all are unity, shared values, solidarity, community and society. Therefore, our definition of social cohesion in higher education is an ongoing process of developing a voluntary community of scholars and practitioners with shared values of Ubuntu to enable members to grow.

\subsection{Who are We?}

The authors of this article are a group of Library (Pam) and academic staff members of a rural university in the Eastern Cape Province of South Africa, with diverse specialisations - Political Studies (Gladys), Anthropology (Kholekile), Life Sciences Education (Tholani), Consumer Studies Education (Mandisa), English (Lazarus), and Health Sciences (KhatryChhetry). Most of us in the group collaborated previously through an interinstitutional Transformational Education/al Studies (TES) research project, whose introduction and development at our institution can be traced to 2010 (Chisanga \& Meyiwa 2019). In that project, the focus was on making meaning for transformative educational research from self-reflexive inquiry, with Theresa Chisanga as the group leader at our university. As one of our 
collaborative research outcomes, we co-authored a book chapter on 'The Vanda, the Rose, and the Baobab: Inspirational Display Objects as Fertile Sites for Opening up Narratives of Teacher Researcher Professional Identities' (Chisanga et al. 2017).

The original five members of TES at our institution were two research supervisors and three university staff members who were doing postgraduate studies. Together, they produced three graduates and a published article to collaboratively reflect on their research journey (Meyiwa et al. 2014). The two supervisors also published an article tracing their journey in establishing TES at the institution (Chisanga \& Meyiwa 2019).

When the current inter-institutional three-year project, Object Inquiry for Social Cohesion in higher education (Pillay, Pithouse-Morgan \& Naicker 2019), came into being in 2019, it just felt natural to continue to collaborate as our university team, even though some members had left while others joined. As with the TES project, we partner with two other universities from the KwaZulu-Natal Province, with one of them leading the project. We attended the first workshop in Durban in July 2019 to kick off the project with an exercise in scavenging for any object/s that appealed to us on the beach. We engaged in other activities in inter-institutional groups, with our team members scattered amongst these groups. From our diverse experiences of the workshop, we came home with a decision that we would engage further as our team to collaboratively write and publish several articles.

In December 2019, we went for a team retreat that mimicked the first workshop. We intended to begin with a scavenging activity, but the weather was so inclement that we stayed indoors. Having taken part in object inquiry before, we had brought some objects that we had been thinking about. We all presented our objects and agreed that the stories of Madiba's Merc (narrated by Gladys) and the 'Thank You' postcard (described by Theresa) were the most relevant for our project. These two objects encapsulated volunteerism, collaboration, Ubuntu, unity of purpose, and self-sacrifice, which we see as characteristic of social cohesion. After this retreat, we met regularly to shape our ideas into a concept to work into an article. We shared our views and feelings about Madiba's Merc and the postcard, and some of these sentiments are shared in this article. We recorded and transcribed our frequent seminar room discussions. We dialogued and identified keywords that led to the themes of this article. 


\section{Theoretical Framework}

The theoretical framework of Reflexive Ubuntu encourages awareness of the interconnectedness 'between the concept of reflexivity and the South African concept of Ubuntu' (Harrison et al. 2012:17). The Reflexive Ubuntu philosophy - which Harrison et al. (2012) describe as a combination of reflecting on our involvement as researchers and the subject of the research taking into consideration our connectedness to others to achieve social cohesion as a unit - guided our dialogue and discussion on how transformation can be achieved for the sake of social cohesion.

Ubuntu has been explained as a way of life that can gently transforms society within and across institutions of higher learning for social cohesion. Ubuntu emphasises the importance of community, solidarity, caring and sharing, interdependence, and partnership with others (Ngcoya 2009:1). Chisanga and Meyiwa (2019:6) expand on this concept when they write,

at the centre of Ubuntu philosophy is the practice of caring for other people, appreciating that due to the interconnectedness between people, it is essential to draw from and put together a variety of resources towards uplifting disadvantaged people.

As such, academics across all institutions of higher learning must work together to uplift one another to promote transformation for social cohesion, a point emphasised by Chisanga and Meyiwa (2019:11).

Individually and collectively, we reflect on the part that each of us can play to achieve social cohesion by incorporating Ubuntu's values. This can change our worldview because of the collaboration with others (Samaras et al. 2019:198). In so doing, we demonstrate the power of the 'we' to develop the 'I' (Pithouse-Morgan \& Samaras 2015:6) for maintaining social cohesion within our higher education institution in South Africa. Concerning the implementation of Reflexive Ubuntu, each participant in our team mentioned the change or enhancement they had experienced in practice, whether with colleagues, students, or society as a whole. Learning or new knowledge arises when researchers reflect on their practices in the light of critical feedback from others - critical friends who help to provide room for questioning traditional practices and personal biases (Samaras 2011). Reflex- 
Gladys M. Ashu et al.

ive Ubuntu guided us as we identified and reflected on Madiba's Merc and the postcard and their significance and symbolism based on the spirit of transformation, self-sacrifice, cohesion and collaboration.

\section{Methodologies}

\subsection{Visual Methodologies}

Visual methodologies are a collection of methods utilised to comprehend and interpret images such as photography, film, video, painting, drawing, collage, sculpture, artwork, graffiti, advertising, and cartoons (Glaw et al. 2017:2). In our case, the images used are a photograph (Madiba's car) and an artwork (the 'Thank You' postcard), and the aim was to create knowledge on social cohesion. Visual methodologies capture rich, multi-dimensional data and add valued acumens into the everyday worlds of participants. The visual image has become central to many modern social and political movements worldwide and how we understand them (Ferguson 2013:1). We used 'Madiba's car' and the 'Thank You' postcard images as researchers and practitioners from different disciplines, acting as an audience to generate verbal discussion on social cohesion in higher education. The aim was to have polysemic voices responding to the images to encourage and illuminate reflections on social cohesion. As affirmed by Ferguson (2013:2), visual methods act as a valid strategy of social inquiry and can illuminate parts of the social world that are unique.

\subsection{Collaborative Object Inquiry through Reflexive Ubuntu}

We used collaboration based on a shared commitment to furthering both the individual's knowledge and collective wisdom (Given 2008). Collaborative inquiry can be a practice of engrossing teachers as researchers in their practice (Comber 2013). Through collaborative inquiry, practitioners work together to advance their understanding of and introduce progress and new advances in educational settings (Comber 2013). Collaboration in the context of this study meant working together with researchers and professionals/ practitioners from different academic disciplines (Comber 2013). Working collaboratively, we examined the images from different perspectives to extract issues of social cohesion. Specifically, as described in the theoretical framework above, we used Reflexive Ubuntu, which combines the two 
concepts of self-reflexivity and Ubuntu. Understanding the core meaning of Ubuntu is critical in any discussion on social cohesion in the higher education landscape, as it is the very basis of a socially cohesive society and what higher education needs in South Africa today.

As part of the collaboration highlighted in the section, 'Who are we?' we engaged in conversations as we shared our views on how we saw our chosen two objects as relevant to this study. We worked on a round-robin method where each member received a draft of this article, made their input, then passed it on to the next member. Every team member's input was regarded as necessary since this was a collaborative effort. Working together in this way also assisted some members who were new to object inquiry.

\section{The Objects and what Informed their Selection for Reflections on Social Cohesion}

The selection of an object of inquiry involves careful consideration of various factors. Our chosen objects have historical and sociocultural significance (Pithouse-Morgan \& Van Laren 2012), as revealed in their denotative meanings (Riggins 1994) offered by Gladys and Theresa in this section. The prompt that assisted in bringing out the denotative meanings was:

- What informed the selection of the objects for reflecting on social cohesion in higher education?

Gladys narrated the background of the red car of Tata Madiba (Nelson Rholihlahla Mandela) as an object of inquiry for transformation and social cohesion:

The workers of Mercedes Benz heard that Mandela was going to be released. Someone came up with the idea, 'Can't we make a car for Mandela?' They sold the idea to everybody, and they accepted. Then their employer donated the parts, and they started to work on the car. Within four days they had built the car, working after hours without pay. The car has a personalized number plate inscribed with 999NRM (with NRM representing Nelson Rholihlahla Mandela), and at the 
front, the car also has a South African flag. The car was handed over to Tata Nelson Mandela on 22 July 1990. It was also reported that as the workers were building the car, there was dancing and jubilation.

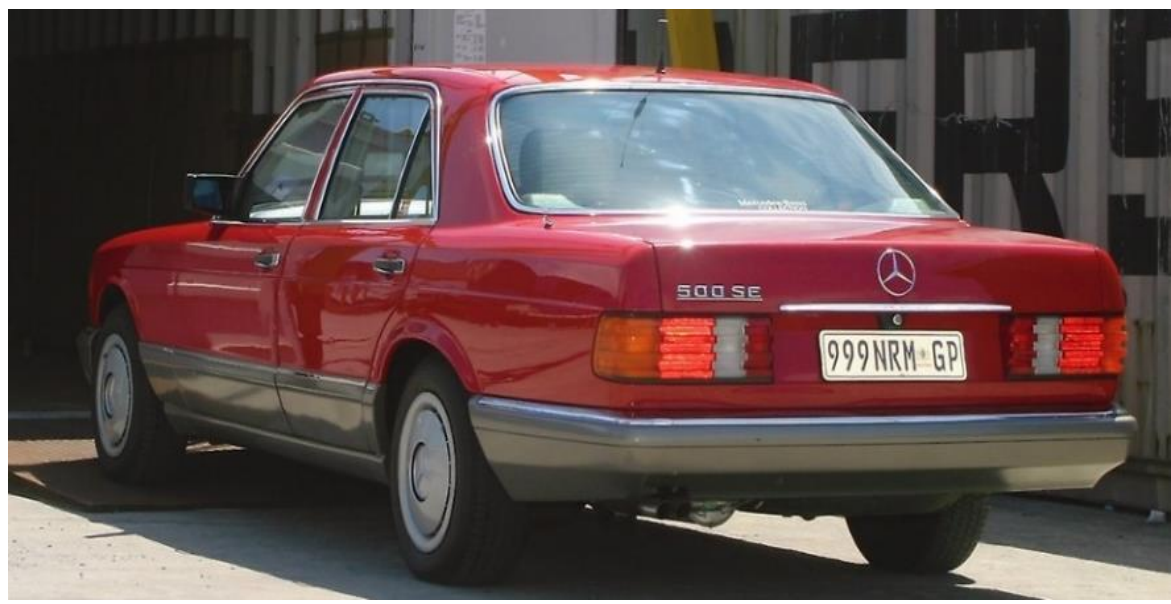

Figure 1: Madiba's Merc (image by Lance Branquinho, Wheels24 2019).

As a collective, we agreed that, as an object, Madiba's red Mercedes Benz (Merc) may make one think of the usual specifications of a Merc. It is a roomy, safe and comfortable car, which in the past was affordable only to wealthy people. It is built so that the safety of occupants therein is almost guaranteed even in case of accidents. It is a car that rarely, if ever at all, overturns. The red colour of Madiba's Merc is bright, appealing, and attractive.

Knowing they were working on a vehicle to be given to such a man as Madiba, the workers could not help but feel greatly honoured to participate in such a project. The personalised number plates of the car gave an identity to the car itself. Wherever it would be parked, it would stand out; it was unique. It would be a car for a very great personality.

The South African flag on it marked it as South African. Standing in juxtaposition with the dominant red colour on the car's body, the black strip at the car's base enhanced its beauty. The contrast had a desirable aesthetic effect. The red colour created a foreground for the black trim. 


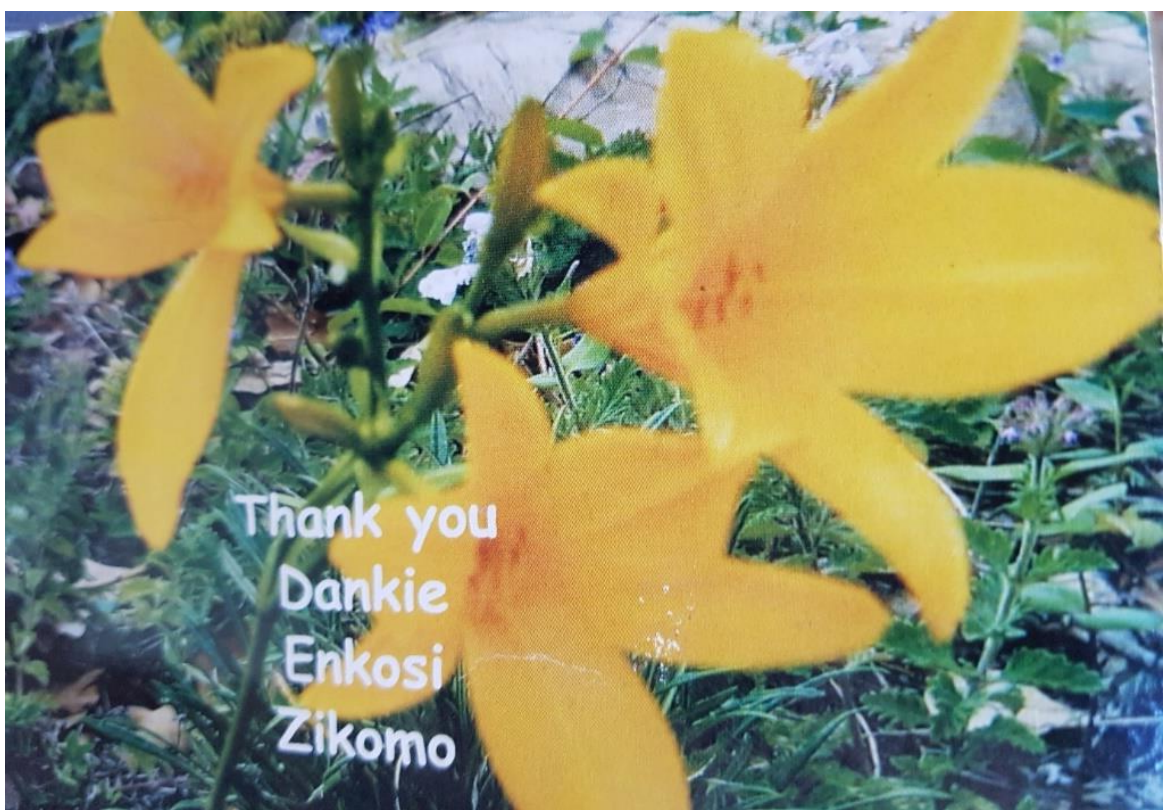

Figure 2: The Thank You Postcard (photographed by Theresa)

Theresa presented the background history for the 'Thank You' postcard that she received from the Clare Sisters as a gesture of love and appreciation for her visit to a convent:

The Catholic nuns gave a postcard to me when I visited them. The wishing card was a gift from a group of nuns to me as a sign of love and appreciation for the visit. The nuns at the convent always pray for all racial groups and the world equally to have peace. The wishing card had 'Thank You' in different languages, with the inclusion of Afrikaans as a sign of inclusion of all races.

We established that, in ordinary circumstances, a 'Thank You' card is a token of appreciation to someone who has done something valued by another. As an object, this particular artefact in this collection is multi-coloured. The flower itself has a bright colour, yellow, and a few red spots in the centre. 
Beyond that, several other colours stand out. Among these colours are green, white and blue. In short, the flower and its surroundings blend many colours, making it stand out, appealing, and attractive to the eye. Apart from the colour mix noted on this card, the inscription of the appreciation presented on the card is eye-catching too. It is expressed in four languages: English, Afrikaans, Xhosa, and Nyanja/Chewa. The last is a language spoken in Zambia and Malawi. This feature of the card points to multilingualism, one of the aims of Democratic South Africa. Multilingualism on a single card symbolises uniting peoples from different language backgrounds, thus, enhancing cohesion through the power of recognising that while there are differences amongst us, we can still find some similarities.

\section{The Symbolism of the Objects to Social Cohesion in Higher Education in South Africa}

What people see in each object at a connotative level (Riggins 1994) varies from one person to another. We discussed how the two chosen objects represent aspects of our thoughts on social cohesion for this study. Our various perspectives and reflections on the objects are presented in light of the denotative meanings given above. The prompts that assisted in bringing out the connotative meanings were as follows:

- What are the symbolic meanings attached to the selected objects?

- What are the reflections of the group members on the meanings attached to the objects?

- What is the significance of these selected objects toward social cohesion in higher education in South Africa?

We see the objects as acts of sacrifice and selflessness made by both the workers (and Tata Madiba) and the Clare Sisters. These values come across as significant when used with reference to social cohesion in higher education in South Africa. The objects further suggest empathy, collaboration, and Ubuntu. We would like to see more of these in our current institution. Participants had this to say: 


\section{Kholekile:}

The red colour of Tata Madiba's Mercedes Benz car is a symbolic representation of the struggle that has been experienced by the previously disadvantaged institutions of higher learning in trying to reach the level of the previously advantaged institutions in research when working in isolation. The brightness of the red colour of the car also symbolises the focal point of the institutions of higher learningresearch and publication, that can be used as a tool for social cohesion for bringing together the previously advantaged and the previously disadvantaged institutions. It also represents the boldness and courage necessary for both forms of institutions of higher learning to approach each other for transformation, collaboration, and social cohesion to share knowledge and experiences with a common goal of improving research and publications.

The red colour of Tata Madiba's Mercedes Benz car symbolises excitement, love, and hope for a brighter and unified South Africa that Mercedes Benz's workers had when they thought of Tata Madiba. It is the same excitement, love, and hope that drive members of the two institutions to have courage and willingness to transform, collaborate and develop each other at all levels for social cohesion and a better future.

Tholani: Tholani thought that both the car and the flower on the postcard symbolise the light and hope for higher education in South Africa and the world. He had this to say:

With Madiba, there was no discrimination. The gift of a car to Tata Mandela and not an airplane symbolised that he was grounded with the people on the ground (ordinary people). The car symbolises a people's person, a person that will be grounded with the grassroots people, a humble person, a humble leader. Red car - the colour connected to the struggles of the people, the blood that symbolises the struggles of the people.

The flag on the car represents all the colours - that all races in South Africa have contributed towards the liberation of the people of South Africa, one way or the other. The flower in the Thank You postcard has a bright colour that can be linked to the light. 
Gladys M. Ashu et al.

Furthermore, on the Thank You postcard, behind the green foliage and flower petals lie patches of clear blue sky. The blue sky comes with a horizon and the horizon comes with symbols of hope that come through social cohesion at South African community grassroots levels and reverberated in institutions of higher learning.

Tholani, therefore, sees the varying levels of brightness of the flower petals as signifying the different levels, patterns, and paces at which people of South Africa would achieve transformed behaviours for social cohesion. That would require patience among all South African people and the world at large since whatever happens in South Africa impacts the worldview of South Africa.

\section{Gladys:}

The objects to me symbolise collaboration, sacrifice, and Ubuntu. In the objects, I realise that I cannot always achieve much when I do research alone or in isolation. That, to come up with a masterpiece kind of research, there must be the need to collaborate and sacrifice; in these two, the values of Ubuntu are embedded.

This car brings forth an emotion of sadness and pain. The communal effort emanating from Ubuntu, which was put in the production of the car, rarely exists in current South Africa and higher education institutions. In that object, I saw a great South Africa that emerged with Nelson Mandela. The object embodies the same qualities that Mandela held and represented.

What is now seen in the nation-state is individualism, corruption, factionalism, nepotism, racism, gender-based violence, xenophobia, crime, etc. Some even say that Mandela would be turning in his grave to see what is happening in today's South Africa.

To extend this to my educational research, I think more collaboration among researchers in higher education institutions is necessary. The object at the time was a Masterpiece C-Class Merc which could not have been possible to achieve by a single individual. It was through a collective effort that made it happen. The red colour of the object symbolizes the sacrifice of the lives lost to achieve freedom. Hence, in collaboration, many sacrifices are done, through the fact that some colleagues would have to sacrifice more of their time and effort to get 
the research right. Sometimes, this is done by the more knowledgeable other (Vygotsky, in Stolle, Frambough-Kritzer, Freese \& Persson 2019). In the same manner, the sisters who created the Thank You card sacrificed their entire lives to a life of solitary and to pray for peace and harmony in the entire world. When we incorporate collaboration and sacrifice, we eventually demonstrate values such as solidarity, empathy, and humanistic concern embodied in Ubuntu. In higher education institutions, we seem to have lost these values. We need to revisit our past and bring back those values which made us work as a collective. This is very important in solving the challenges facing us today as they require the collective effort of researchers and practitioners to work critically in solving such challenges. Suppose researchers and practitioners in higher education could follow the example of the workers at the Plant and the Sisters and work together. In that case, higher education institutions may have a sustainable solution to many of the problems facing the world today.

\section{Lazarus:}

Social cohesion places value on every role player. The powerful do not overlook the views of those under them. The owners or captains of the Benz Motor industry in South Africa listened to their workers. Social cohesion has room for views from the bottom- to the top as opposed to the top-down flow of ideas. Beyond the denotative level of perceiving these objects, there lies a connotative level of perception of each of these two objects. At this level, the notion of social cohesion comes into consideration to which one's mental eye may turn.

To begin with, the red colour is associated with danger, but as Madiba himself put it, the red colour of his car represents the blood that was shed in pursuit of a South Africa that would belong to all living in it. Looking at the bloodshed in liberation wars that brought democratic South Africa, one cannot help but wish and hopefully strive to achieve social cohesion envisaged by Madiba and other leaders who sought to reach such a goal. The multiplicity of colours noted on the card points to social cohesion the new South Africa was expected to achieve. The four languages used to express the appreciation the card is supposed to convey also point to a desire and drive towards social cohesion in education and society. 
Gladys M. Ashu et al.

\section{Khatry-Chhetry:}

The Madiba car symbolised the possibility and victory and its usefulness, which could be considered as a treasury for the youth of today's South Africa.

It is also a symbol of legacy, appreciation of the gratitude of Madiba.

The car symbolises the celebration of the victorious release of Madiba. It is an old car, but it still has an impact on people.

\section{Pam:}

Madiba, as a true leader, on his release from prison, in his first public address to his supporters (Cape Town City Hall foyer) in 1990, [he] said: 'I stand here before you not as a prophet, but as a humble servant of your people'. This indicates that leaders should always humble themselves to be accepted by every individual in society. As researchers and leaders, we are to foster enduring forms of social justice, peace, and restore trust in higher learning institutions.

The 'Thank you' in different South African languages in the wishing card indicates that we must acquaint ourselves with more than one language as South African citizens. This will enable us to communicate better with each other, [and] bring, [and] foster unity and social cohesion. In institutions of higher learning, being multilingual will enable one to feel comfortable in learning other languages to improve the relationship and accept one another As an institution that is aimed to forge unity of purpose among staff and students to achieve transformation, change and promoting values of a new institutional culture is necessary. As collaborative researchers and agents of change, we come up with new ideas and knowledge during our research process in our research strategy. This will enable us to establish programs for transformation, build social cohesion, and promote equitable, inclusive, equal access to quality education for our students in higher educational institutions in South Africa.

\section{Mandisa:}

Mandela modelled self-sacrifice for the nation. He did not expect anything in return, as he was even prepared to die for his ideal of a democratic, coherent society. The workers at the Mercedes plant 
emulated Madiba's sacrifice when they assembled the car and gifted it to him. His sacrifice also led to the first time that the nation displayed a cohesion never achieved before when the whole country went to the polls as one in 1994. Our university is not the most popular in the country, but our catchment area is made up of some of the most impoverished communities in the country. The students come from homes where lots of sacrifices are made to send them to university. By the same token, staff generally try to work to encourage success for the students. This, for me, indicates that social cohesion can be achieved in our higher education sector.

The spirit of gratitude, which is one of the characteristics of humility, is significant in a leader. That the nuns took the trouble to make the postcard by hand is very significant. They, like Madiba, sacrifice their lives for the benefit of the nation. They also work in a team like the workers of the Mercedes Benz plant. For me, the message from these two objects is sacrifice, humility, and gratitude, both of which can immensely influence the extent of social cohesion in any higher education institution.

In addition to extending our understandings of social cohesion in higher education, the collaboration and self-reflexivity we experienced in this research project have enhanced our vision of social cohesion in practice. This is evident in the way we interact with our colleagues, students, and society as a whole, as exemplified by comments below:

\section{Lazarus:}

Since 2016 when, for the first time, I attended a Transformative Education through Self-Study (TES) workshop, my perception of research has changed. To begin with, it was my perception of 'reflecting on a workshop' that changed. Asked to reflect on that very first TES workshop, I focused on things I thought did not happen the way I thought they should have. Group members who had been in the system already drew my attention to what reflection means in selfstudy research. Most of all, the collaboration I have found in this research group has made research less daunting than I ever thought it was. The group in constitution and nature can be classified as an epitome of social cohesion in an institution of Higher Learning. 
Gladys M. Ashu et al.

The most significant impact of my association with my colleagues in our TES team is that the more I reflect on objects and value in them, I reflect on my practice the more. I see immense potential in every student of mine and encourage reflexive thinking and collaboration among themselves. In a way, small as it may be, it instils social cohesion amongst students regardless of social factors that divide people, such as specialisation, ethnicity, gender, and race, to name just a few. Social cohesion instilled in my students at the university I practice my career as an educator may filter through into society where they and I live and function.

\section{Gladys:}

There is a bit of a shifting perspective in the way I now interact with my students and colleagues. I am now more accommodating and have a willingness to listen more to other peoples' viewpoints. I understand more about the values expressed in the word 'Ubuntu' in the way I relate with my colleagues and other people. Furthermore, there is also that critical realism angle when dealing with my students, more especially when they contact me concerning their challenges or problems faced in their studies.

\section{Tholani:}

Working with other academics from other faculties and disciplines enabled me to understand similarities in what I used to perceive as different fields. Based on my science-inclined quantitative research approach background, through working with others from other disciplines, I came to understand the power of the qualitative research approach, which brings out the details embedded in social settings. As an academic and researcher, I realised that the qualitative approach elicits pertinent details embedded in our minds that may never be fully unveiled from the quantitative scientific approach alone.

\section{Khatry-Chhetry:}

Generally, I used to advise the students to follow the formal university channel of communication to report their grievances. But now, I attend to their issues, thinking about the possible story behind it and 
finding out how it would influence their teaching and learning performances. I realised that most of the time, the student suffers tremendous stress even with a minor issue. Hence, I listen carefully to the comments and criticism made by the students and colleagues and try to find its essence, which is adding value in academic teaching and learning, so I bring more satisfaction in my daily life.

\section{Discussion: Significance of the Objects toward Social Cohesion in Higher Education in South Africa}

In this section, we discuss the themes generated from our research. We circle back to the main research question, 'What can we learn about social cohesion in higher education through object inquiry?' Our connotative voices about the objects raise themes such as collaboration, cultural change and diversity, leadership, sacrifice and selflessness in the realisation of social cohesion and transformation in higher education. These are discussed hereunder:

\subsection{Collaboration}

According to Dooly (2008), collaboration is about [a team] working together to achieve a common goal. However, our version of collaboration goes beyond this definition. We view our partnership more in line with the Donald Campbell model of science that highlights the benefit of collaboration; that science is the most effective when researchers with expert knowledge in different areas collaborate on a project of overlapping interest (Sprunger 2017). In our project, although we may not all have specialist knowledge in object inquiry, through collaboration, we managed to carry out this study. We had regular sittings to discuss the research, shared ideas, distributed sections of the study to work on privately, then met for further discussions.

Our collaboration was only possible because we embraced the values of Ubuntu, believing they would assist us in counteracting the adverse effects of individualism, discrimination, and self-centeredness that have bedevilled researchers and practitioners at higher education institutions. By putting together the Merc and the postcard to elicit and pool different ideas, attitudes, values and reflections, it becomes easier for us to develop new knowledge inclined to facilitate changes in our perceptions of the educational system and society as a whole. The connectedness during an object inquiry from 
diverse contents generates and brings about considerable research knowledge, as ideas emanate from lived experiences of the researchers. The narratives that we have offered in our attempts to interpret the selected objects for meaning-making at the individual level create awareness of our social situatedness (Dirkx 2001).

Identities of race, gender, ethnic origin, or social standing are significant in higher education. And we can bridge these differences with the help of Ubuntu to achieve transformation for social cohesion. As acknowledged by Chisanga and Meyiwa (2019:7), 'we carry a lot of identities between us' and have to learn to 'walk the path carefully as we negotiate our identities'. We see our objects as embodying the virtues expressed in the philosophy of Ubuntu. For example, it was through a collaborative effort that Madiba's car was manufactured within four days. Similarly, in the 'Thank You' postcard, the sisters collaborated to create a card that communicated the word 'thank you' in different languages. The emotions triggered by the Merc echo the sentiments that come to the fore amid the struggles that staff face in our institution regarding scholarly publication. However, through collaborative efforts, they tend to smile when an article or chapter is eventually published. This was actually the case in 2017 when we published a book chapter as co-authors in a manner reminiscent of Mandela's famous inspirational phrase that 'it always seems impossible until it is done'.

\subsection{Cultural Change and Diversity}

There are also possibilities of transformation and social cohesion within our university through cultural change and diversity. To some of us, Madiba's car symbolised opportunities for victory through transforming ways of doing things by changing from cultural practices of the apartheid era to incorporating African indigenous ideas such as Ubuntu and freedom. These concepts foster the restoration of communal harmony (Ngcoya 2009) in the curricular and general practice of members of the institution. Tholani viewed the bright colours of the flower petals with varying levels of brightness as an indication that they had not been exposed to the sun at the same time. The flower's brightness symbolised the hope and possibility for light and a brighter future for our institution with researchers of varying backgrounds, limited strengths, and many weaknesses (Bresler 2008:230). Therefore, 
contributing to the institutional transformation and social cohesion initiatives would mean that academics meaningfully change in their 'personal capacities and thinking' (Sayed et al. 2016:8). By so doing, this may create space for 'constant learning from each other', which is a 'two-way process' (Chisanga \& Meyiwa 2019:14; Dhlula-Moruri et al. 2017:92). Furthermore, Ngcoya (2009) attests that creating that space for constant learning from each other does inculcate a profound sense of interdependence and emphasis on the true human potential that can only be realised in partnership with others. This may lead to the desired outcome of transformation and social cohesion, such as 'to bring communities together and help build solidarity, trust, and inclusion' (Sayed \& Badroodien 2016:3). The interpretation of these two objects that carried 'cultural and historical significance' (Pithouse-Morgan \& Van Laren 2012) became more apparent in the reflections offered by the participants. Their thoughts unveiled the depth and sensitivity of the challenges concerning possibilities of transformation and social cohesion within our institution.

\subsection{Leadership}

Mandela's Merc and the Clare Sisters' postcard suggest what could be expected from the leaders of the collaborative research group as they have to be models in the group. They have to sacrifice a lot and facilitate unity within the group. The stories of Tata Madiba and the Clare Sisters have been 'triggered' by the two 'objects', the car and the wishing card, as another attempt to address issues of transformation for social cohesion. This collaborative research group can unify and develop young academics with support from experienced researchers within our institution. Leaders of the collaborative research group sacrifice their time whenever they sit in meetings, whenever they invest in unifying the group or reviewing manuscripts developed by the developing researchers. When leaders execute their responsibilities within the group, they also have to apply critical reflexivity, especially considering their origins, as pointed out by Scott (2014), because this is crucial for successful transformation and social cohesion within and across institutions of higher learning.

The responsibility of the collaborative research leaders, of guiding the developing researchers and writers, has to be accompanied by the act of Ubuntu which is underpinned by patience and compassion. This is in line 
with the arguments of Ngcoya (2009) and Bresler (2008), who both point out that academic leaders need empathy to support developing researchers successfully. For transformation and social cohesion to be successful within our institution, these should be in the agenda and programmes of the institution. It is collaborative research leaders who are responsible for training the developing researchers and writers on how each individual is expected to play a significant role in the collective group to achieve transformation and social cohesion (Pelias 2008). At this stage, one can also visualise the characteristics of a leader (project leader) whereby one participant (Tholani) mentioned being 'grounded' with grassroots people, as the case was with Mandela, who understood the struggles of the people in a non-discriminatory way. Thus, participants highlighted that emotions regarding the release of Mandela include excitement for the freedom that Mandela stood for and celebrations for the release and victory of Mandela. They also pointed to the significance Madiba's car has concerning his statement that 'it always seems impossible until it is done'. Whenever people look at the car, they see a symbol of a great leader.

\subsection{Sacrifice and Selflessness}

Looking at the theme of sacrifice and selflessness, we draw from Singh and Krishnan's (2008) discussion of the distinction between 'self-sacrifice' and 'altruism'. The difference between these two is that the first may not be directed at 'another' person or object. The second is always directed at 'another'. Regarding Madiba's red Merc, as an object, we see altruism because Madiba sacrificed his personal freedom, comfort and luxuries for the good of all South Africans. Workers at the Benz Motor company recognised and responded to that kind of sacrifice. Without being asked by Madiba himself, they decided to build a Merc for him when he was about to be released from prison. Workers sacrificed their own free time, including lunch hours, to complete the work within four days. The company management made the required materials available to the workers to build that car. The company sacrificed the profits that the company would have made from the sale of that car if they had to sell it. The sacrifice made by one person, Mandela, made others sacrifice what they could in appreciation of his own personal sacrifice.

The spirit of sacrifice we saw in Madiba's red Merc, we also saw in 
the 'Thank you' postcard. The sisters sacrificed their own time to design the card and word it in the manner they did. The inclusion of Chewa, a language mainly spoken in Lusaka and the Eastern part of Zambia, made the recipient of the card, Theresa, feel socially integrated into the South African society. Furthermore, the inclusion of Afrikaans, a language once considered a language of white oppressors, the Afrikaners, is a move in the direction of social cohesion. Reflecting on this study, we see the theme of sacrifice and selflessness applying to ourselves as a research group. As a group, we are at different levels of competence in research. The experienced sacrifice their time to enable beginner researchers to learn the art of research. We have classes to teach and other academic work to do, but we sacrifice our time to meet and work on group papers for publication.

\section{Conclusion}

Through the object-based inquiry project, we, as a diverse group of researchers and practitioners from different disciplines within our institution, demonstrated the need to reimagine social cohesion through Mandela's Merc and the 'Thank You' postcard. We did so by using collaboration, selfreflexivity, and Ubuntu. The collaborative effort of the workers and their manager brought about that masterpiece of a car. The workers had the skills but not the money to buy the car parts. Thus, their employer came in to fill that gap. The same applies to the sisters in the 'Thank You' postcard with different languages. It was only because the sisters collaborated that they could come up with a postcard that displays those languages to accommodate all groups of people in the country.

Furthermore, our participation in this project has impacted us individually and collectively and in our practices, as we now view social cohesion and transformation through a different lens. Subsequently, we identified the need to come up with similar projects. We also envisaged the need to bring forth this inquiry to involve more young academics and students to have continuity when some of us retire and leave the institution. Lastly, having such academics integrate their experiences within a university that is already taking transformation issues seriously may influence social cohesion and collaboration issues in future developmental projects in the institution.

The car assembly for Madiba involved a group of workers who 
worked selflessly without pay for long hours. We also worked collaboratively as academics from different disciplines in this inquiry. This illustrates the significance and power of working together with a common purpose. In institutions of higher learning, the insight that arises from this is that social cohesion within and amongst institutions can be enhanced if institutions adopt a philosophy of 'I am because you are, you are because I am'. This could pave the way for those universities that were not historically disadvantaged to be involved in collaborative partnerships instead of competing with the historically disadvantaged universities. Similarly, we could form collaborative partnerships in research, teaching and administration at a single institution and with other universities. This could result in social cohesion and having expertise shared across departments, faculties and universities for a better South African higher education system. As academics in this inquiry, we have also come to realise the significance and impact of others in shaping our thinking, reflections and practice in ways that make us work better with and amongst others.

Though made from a mere picture of foliage and flowers, the postcard has insights we drew from as academics at an institution of higher learning. The different languages used on a single card point out that while there are linguistic differences amongst us, we can still find similarities in those differences in our quest to enhance social cohesion. As universities and academics at institutions of higher learning, although we have differences in terms of our expertise across different disciplines, these differences can be brought together in our quest to enhance social cohesion for the benefit of all - academics, universities, administration staff and students. Each university is a microcosm of society. Thus, if each of the institutions of higher learning realises and enacts social cohesion practices, these would become epicentres and grassroots levels for social cohesion, which would filter to different communities, societies, and eventually the entire country at large.

\section{Acknowledgments}

We thankfully acknowledge Theresa Chisanga who did not contribute to the writing of this paper but assisted in the identification and generation of the data produced in the study. We equally acknowledge funding from the NRF via UKZN for the project. 


\section{References}

Badat, S. 2010. The Challenges of Transformation in Higher Education and Training Institutions in South Africa. Development Bank of South Africa $8,1: 1-37$.

Bresler, L. 2008. Research as Experience and the Experience of Research: Mutual Shaping in the Arts and in Qualitative Inquiry. LEARNing Landscapes 2,1: $267-281$.

https://doi.org/10.36510/learnland.v2i1.288

Chisanga, T., G. Ashu, P. Mavume, M. Dhlula-Moruri, M. Khatry-Chhetry,

S. Rajkaran, L. Mulenga, N. Sotshangane, N. Gonsalves, P. du Toit \& D. Pillay 2017. The Vanda, the Rose, and the Baobab: Inspirational Display Objects as Fertile Sites for Opening up Narratives of Teacher Researcher Professional Identities. In Pillay, D., K. Pithouse-Morgan \& I. Naicker (eds): Object Medleys: Interpretive Possibilities for Educational Research. Rotterdam: Sense Publishers.

https://doi.org/10.1007/978-94-6351-194-0_5

Chisanga, T. \& T. Meyiwa 2019. Reflexive Ubuntu, Co-Learning and Transforming Higher Education at a Rural University in South Africa.

In Kitchen, J. (ed.): $2^{\text {nd }}$ International Handbook of Self-Study of Teaching and Teacher Education. Springer International Handbooks of Education. Dordrecht: Springer. https://doi.org/10.1007/978-981-13-1710-1_52-1.

Comber, B. 2013. Teachers as Researchers: A 'fair dinkum' Learning Legacy. English in Australia 48,3: 54 - 61.

Dhlula-Moruri, M.N., M. Kortjass, T. Ndaleni \& K. Pithouse-Morgan 2017. A Stove, a Flask and a Photograph: Learning Together through Object Inquiry in Self-study Research. In Pillay, D. et al. (eds.): Object Medleys. Rotterdam: Sense Publishers. https://doi.org/10.1007/978-94-6351-194-0_6

Dirkx, J.M. 2001. The Power of Feelings: Emotion, Imagination, and the Construction of Meaning in Adult Learning. New Directions for Adult and Continuing Education 89: 63 - 72. https://doi.org/10.1002/ace.9.

Dooly, M. (ed.). 2008. Telecollaborative Language Learning: A Guidebook to Moderating Intercultural Collaboration Online. Bern: Peter Lang. Ferguson, T.S. 2013. Using Visual Methods in Social Science Research. $3^{\text {rd }}$ Edition. Oxford University Press: Melbourne. 
Gladys M. Ashu et al.

Fonseca, X., S. Lukosch \& F. Brazier 2019. Social Cohesion Revisited: A New Definition and How to Characterize it. Innovation: The European Journal of Social Science Research 32,2: 231 - 253.

https://doi.org/10.1080/13511610.2018.1497480

Given, L.M. 2008. The SAGE Encyclopaedia of Qualitative Research Methods. Thousand Oaks, CA: SAGE Publications, Inc. https://doi.org/10.4135/9781412963909

Available at: https://methods.sagepub. com/reference/sage-encycqualitative-research-methods/n51.xml (Accessed on 01 May 2020.)

Glaw, X., K. Inder, A. Kable \& M. Hazelton 2017. Visual Methodologies in Qualitative Research: Autophotography and Photo Elicitation Applied to Mental Health Research. International Journal of Qualitative Methods 16, $1-8$.

https://doi.org/10.1177/1609406917748215

Harrison, L., K. Pithouse-Morgan, J. Conolly \& T. Meyiwa 2012. Learning from the First Year of the Transformative Education/al Studies (TES) Project. Alternation 19,2: 12 - 37.

http://alternation.ukzn.ac.za/Files/docs/19.2/02\%20Har.pdf

Kantzara, V.2016. The Relation of Education to Social Cohesion. Social Cohesion and Development 6,1: 37 - 50.

https://doi.org/10.12681/scad.8973.

Mandela, N.R. 1995. Long Walk to Freedom: The Autobiography of Nelson Mandela. London: Back Bay Books.

Meyiwa, T., T. Chisanga, P. Mokhele, N. Sotshangane \& S. Makhanya 2014. Complex Journeys and Methodological Responses to Engaging in Selfstudy in a Rural Comprehensive University. Perspectives in Education 32,2 .

Mkhize, T. 2019. Social Cohesion: Origins, Definitions, and Dimensions. In Ballard R. (ed.): Social Cohesion in Gauteng. GCRO RESEARCH REPORT 10.

Moiseyenko, O. 2005. Education and Social Cohesion: Higher Education. Peabody Journal of Education 80,4: 89 - 104.

https://doi.org/10.1207/S15327930pje8004 7

Nesterova, M., M. Dielini \& A. Zamozhskyi 2019. Social Cohesion in Education: Cognitive Research in the University Community, International Journal of Cognitive Research in Science, Engineering and 
Education 7, 2: $19-27$.

https://doi.org/10.5937/IJCRSEE1902019N

Ngcoya, M. 2009. Ubuntu: Globalization, Accommodation, and Contestation in South Africa. Doctoral thesis, American University Press.

Pelias, R.J. 2008. Performative Inquiry, Embodiment and its Challenges. In Knowles, J. \& A. Cole (eds): Handbook of the Arts in Qualitative Research, Perspectives, Methodologies, Examples and Issues. Thousand Oaks, CA: Sage.

Pillay, D., K. Pithouse-Morgan, \& I. Naicker 2019. Editorial: 'Not just an object': Making Meaning of and from Everyday Objects in Educational Research for Social Change. Educational Research for Social Change 8,1: vii - xii. Available at:

http://ersc.nmmu.ac.za/view_edition.php?v=8\&n=1\# (Accessed on 07 June 2021).

Pithouse-Morgan, K. \& A.P. Samaras 2015. The Power of 'We' for Personal and Professional Learning. In Pithouse-Morgan, K. \& A.P. Samaras (eds): Polyvocal Professional Learning through Self-study Research. Rotterdam, The Netherlands: Sense Publishers. https://doi.org/10.1007/978-94-6300-220-2

Pithouse-Morgan, K. \& L. van Laren 2012. Towards Academic Generativity: Working Collaboratively with Visual Artefacts for Self-study and Social Change. South African Journal of Education 32, 4: 416 - 427. https://doi.org/10.15700/saje.v32n4a662

Riggins, S. 1994. Fieldwork in the Living Room: An Autoethnographic Essay. In Riggins, S. (ed.): The Socialness of Things: Essays on the Socio-semiotics of Objects. Berlin: Moutin de Gruyter.

https://doi.org/10.1515/9783110882469

Samaras, A.P. 2011. Self-study Teacher Research: Improving Your Practice through Collaborative Inquiry. Thousand Oaks, California: Sage.

Samaras, A., M. Hjalmarson, L.C. Bland, J.K. Nelson \& E.K. Christopher 2019. Self-Study as a Method for Engaging STEM Faculty in Transformative Change to Improve Teaching. International Journal of Teaching and Learning in Higher Education. 31, 2: 195 - 213.

Sayed, Y. \& A. Badroodien 2016. Teachers and Social Cohesion in the Global South: Expanding the Notion of Education Quality. Education as Change 20,3: 1 - 14. https://doi.org/10.17159/1947-9417/2016/1975 
Gladys M. Ashu et al.

Sayed, Y., A. Badroodien, T. Salmon \& Z. McDonald 2016. Social Cohesion and Initial Teacher Education in South Africa. Educational Research for Social Change 5,1: $54-69$.

https://doi.org/10.17159/2221-4070/2016/v5i1a4

Scott L. 2014. 'Digging deep': Self-study as a Reflexive Approach to Improving my Practice as an Artist, Researcher and Teacher. Perspectives in Education 23,2: 69 - 88.

Singh, N. \& V.R. Krishnan 2008. 'Self-sacrifice and Transformational Leadership: Mediating Role of Altruism. Leadership and Organisational Development Journal 29,3: 261 - 274.

https://doi.org/10.1108/01437730810861317

Sprunger, J.G. 2017. The Benefits of Engaging in Collaborative Research Relationships. Available at:

https://www.psychologicalscience.org/observer/the-benefits-of-

engaging-in-collaborative-research-relationships

(Accessed on 2 July 2021.)

Stolle, E., C. Frambaugh-Kritzer, A. Freese \& A. Persson 2019. Investigating

Critical Friendship: Peeling Back the Layers. Studying Teacher Education 15: 19 - 30.

https://doi.org/10.1080/17425964.2019.1580010

Wheels 24. 2019. \#MandelaDay: From Release to Retirement - The Cars of Madiba's Life. Available at:

https://www.news24.com/wheels/News/mandeladay-from-release-toretirement-the-cars-of-madibas-life-20190718

(Accessed on 13 December 2019.)

Gladys M. Ashu

Senior Lecturer

Department of Social Sciences Walter Sisulu University, Mthatha gashu@wsu.ac.za

Dr. Mandisa N. Dhlula-Moruri Department of Mathematics, Natural and Consumer Science Walter Sisulu University mmoruri@wsu.ac.za 
Associate Professor Mukund Khatry-Chhetry (KC) Department of Family Medicine and Rural Health Walter Sisulu University Mthatha

MKhatry-Chhetry@wsu.ac.za

Elizabeth Pamela Mavume Senior Librarian WSU Library and Information Services Technical Services Department Mthatha Campus Libraries. emavume@wsu.ac.za

Lazarus Chifumbe Mulenga Department of Arts Faculty of Humanities, Social Sciences \& Law Walter Sisulu University lmulenga@wsu.ac.za

Dr. Kholekile Hazel Ngqila Senior Lecturer Medical and Cultural Anthropology Walter Sisulu University kngqila@wsu.ac.za

Dr. Tholani Tshuma Department of Mathematics, Natural and Consumer Science Walter Sisulu University ttshuma@wsu.ac.za 